\title{
Formação continuada: implicações e possibilidades no exercício profissional do assistente social
}

\section{Continuous Education: Implications and Opportunities for de Professional Activity of Social Workers}

\author{
Ana Maria Baima Cartaxo \\ Universidade Federal de Santa Catarina (UFSC) \\ Vania Maria Manfroi \\ Universidade Federal de Santa Catarina (UFSC)
}

Maria Teresa dos Santos

Universidade Federal de Santa Catarina (UFSC)

Tradução para o inglês de Jeffrey Hoff.

Formação continuada: implicações e possibilidades no exercício profissional do assistente social Resumo: O objetivo deste artigo é refletir sobre a formação profissional continuada crítica no campo do exercício profissional de Serviço Social. Fundamenta-se em uma pesquisa bibliográfica e documental que procura identificar e apontar estratégias para esse processo de formação. Aborda criticamente a utilização do termo, tendo como referência autores da área de educação. Problematiza a formação continuada como um processo constante e necessário ao exercício profissional, imbricado na relação teórico-prática, na qualidade da produção documental, na apropriação das novas tecnologias para auxiliar a organizar os dados da realidade que se apresentam no cotidiano profissional. A partir do método crítico-dialético, enfatiza a necessária atitude investigativa e propõe estratégias teóricopolíticas de formação continuada para o fortalecimento do projeto ético-político do Serviço Social.

Palavras-chave: Formação continuada. Serviço Social. Relação teórico-prática.

Continuous Education: Implications and Opportunities for the Professional Activity of Social Workers Abstract: The purpose of this article is to reflect on continuous and critical professional education in the field of the professional exercise of Social Work. It is based on bibliographic and documental research that sought to identify and indicate strategies for this educational process. It critically analyzes the use of the term, using as a reference authors from the field of education. It problematizes continuous education as a constant and necessary process for professional exercise that is imbricated in the relationship between theory and practice, in the quality of document production and in the appropriation of new technologies to assist in organizing the data about reality that is presented in the daily work of professionals. Based on a critical-dialectic method, it emphasizes the need to have an investigative attitude and to propose theoretical-political strategies for continuing education to strengthen the ethical-political project of Social Work.

Keywords: Continued education. Social Work. Relationship theory-practice. 


\section{Introdução}

O tema proposto origina-se da preocupação das autoras com o exercício profissional em relação ao Projeto Ético-Político da profissão. Desenvolveu-se a partir das investigações realizadas sobre o exercício profissional e da experiência de supervisão acadêmica das autoras e está fundamentado em bibliografia crítica nos campos temáticos da educação e do Serviço Social.

Pensar a formação continuada dos profissionais em sua prática direta no interior das instituições e organizações não é uma tarefa fácil. Coloca-se, no entanto, como de capital importância no debate profissional, considerando a densidade da produção teórica e a necessidade de sua expressão, com as devidas mediações, em direção à prática qualificada dos assistentes sociais. Marilda Iamamoto (1999) já chamou atenção para esse aspecto ao fazer um balanço dos avanços e desafios da profissão na década de 1980.

Isto instigou a elaboração deste trabalho com o objetivo de contribuir para o debate da profissão nesse campo, ou seja, da formação continuada dos profissionais.

Como pensar esta formação? Que elementos são determinantes nesta compreensão? É claro que não se pretende fazer um estudo aprofundado na investigação mais totalizante dessa temática, mas se ousa suscitar, indagar e inquietar para que novos estudos venham a ser adensados.

Ao se falar de formação continuada, remete-se, necessariamente, à relação entre teoria e prática, à articulação entre universidade e sociedade e à relação entre a produção acadêmica e o exercício profissional dos assistentes sociais.

\section{Formação continuada para além das neces- sidades do mercado}

Falar da importância da educação na atualidade tornou-se lugar comum, já que há uma forte ideologia disseminada pelo mercado que reduz a educação à qualificação profissional, como condição para a inserção e o sucesso do indivíduo no mercado de trabalho. O sucesso e o fracasso são vistos como produtos do esforço individual do trabalhador.

No capitalismo, é preciso qualificar o trabalhador para responder às necessidades da produção. Dos trabalhadores, é exigido não só eficiência material e objetiva, como também uma eficiência subjetiva e diversificada, para que haja compatibilidade com o tempo produtivo e financeiro da produção globalizada (BRITO, 2007).

Segundo Frigotto (2009), a relação da educação com a economia ocorre desde o final da década de 1950, quando o economista Theodore Schultz (1973)

\section{Introduction}

The theme proposed originates from the authors' concern for professional activity in relation to the Political Ethics Project for the profession. The paper is based on research conducted about professional activity and the authors' experience with academic supervision and conducts a critical bibliographical review in the fields of education and Social Work.

To consider the continuous education of professionals in their direct practice within institutions and organizations is not an easy task. Nevertheless, it has extreme importance in the professional debate, considering the density of theoretical production and the need for its expression, with the proper mediations, to strive for the qualified practice of social workers. Marilda Iamamoto (1999) called attention to this factor by providing a review of the advances and challenges of the profession in the 1980s.

This instigated the preparation of this essay with the objective of contributing to the debate about the continuous education of professionals.

How can this education be considered? What elements are determinant for understanding it? The intention is obviously not to conduct an in-depth study based on comprehensive research, but to dare to instigate, question and provoke new studies.

Speaking of continuous education necessarily involves the relationship between theory and practice, the articulation between university and society and the relationship between academic production and the professional exercise of social workers.

\section{Continuous education beyond the needs of the market}

To speak of the importance of education today has become common place, given that the market promotes a strong ideology that reduces education to professional qualification, as a condition for the insertion and success of an individual in the labor market. Success and failure are seen as products of a workers' individual effort.

In capitalism, it is necessary to qualify the worker to respond to the needs of production. Workers are required to provide material and objective efficiency, as well as subjective and diversified efficiency, so that there is compatibility with the productive and financial timing of globalized production (BRITO, 2007).

According to Frigotto (2009), there has been a relationship between education and the economy since 1950 when economist Theodore Schultz (1973) developed the concept of "human capital" to explain inequality between nations, social groups and individuals, without, however, relating it to the true causes - the inequality between private property, 
desenvolve o conceito de "capital humano", para explicar a desigualdade entre nações, grupos sociais e indivíduos, sem, contudo, relacioná-lo às verdadeiras causas - a desigualdade entre a propriedade privada, detentora dos meios e instrumentos de produção e os trabalhadores, detentores da força de trabalho. Schultz identificou que nos Estados Unidos o forte investimento das pessoas nelas mesmas, desencadeava um significativo crescimento econômico. Esse investimento era o capital humano, constituído basicamente de investimento em educação, além do investimento em saúde.

A partir disso, Schultz (1973 apud FRIGOTTO, 2009, on-line) dedicou-se sistematicamente à construção deste conceito, tendo como premissa

[...] que o componente da produção que decorre da instrução é um investimento em habilidades e conhecimentos que aumenta as rendas futuras semelhante a qualquer outro investimento que uma nação ou indivíduos fazem na expectativa de retornos adicionais futuros.

A concepção de "capital humano" desenvolvida por Schultz rendeu-lhe um prêmio Nobel de Economia em 1979, expressando o reconhecimento desta visão para explicar a desigualdade social entre os países e também entre os indivíduos (FRIGOTTO, 2009).

A ideia de capital humano, então, reduz a educação às necessidades mercadológicas, como um fator de produção que ajuda a compreender a visão dominante da qualificação profissional como determinante para o sucesso profissional. Na atualidade, com a crise do modo de produção capitalista, a noção de capital humano vem sendo revista e substituída por sociedade do conhecimento, qualidade total ou pedagogia das competências e empregabilidade ${ }^{1}$.

Assim, concorda-se com Frigotto (2000) quando afirma que as noções de capital humano, sociedade do conhecimento, qualidade total ou pedagogia das competências são conceitos ideologizados que foram construídos para manter inalterados os interesses daqueles que detêm os meios de produção e não contribuem para desvelar a exploração do trabalhador na sociedade contemporânea.

Em relação à UNESCO, também não se percebe ruptura com a noção de educação e qualificação para o trabalho, ainda que se pretenda ampliar o conceito. A discussão sobre a educação continuada ocupa lugar de destaque nos trabalhos da Comissão Internacional sobre Educação para o Século 21, coordenada por Jacques Delors. Tem em vista a superação dos conceitos de educação continuada ou permanente pela "educação ao longo de toda a vida", fundada nos quatro pilares da educação: aprender a conhecer, aprender a fazer, aprender a viver juntos e aprender a ser. Nessa perspectiva, a educação ao longo which controls the means and instruments of production and workers, who maintain only the power of their labor. Schultz identified that in the United States, the strong investment by people in themselves led to significant economic growth. This investment was human capital, constituted basically by an investment in education, in addition to an investment in health.

Based on this, Schultz (1973 apud FRIGOTTO, 2009 , on-line) systematically dedicated himself to the construction of this concept, with the premise

[...] that the component of production that is due to instruction is an investment in abilities and knowledge that increase future income similar to any other investment that a nation or individual makes in the expectation of additional future returns.

The concept of "human capital" developed by Schultz led to his receipt of the Nobel Prize in Economics in 1979, expressing the recognition of this vision to explain social inequality among countries and also among individuals (FRIGOTTO, 2009).

The idea of human capital thus reduces education to market needs, and sees it as a factor of production that helps to understand the dominant vision of professional qualification as a determinant for professional success. With the current crisis in the capitalist mode of production, the concept of human capital has been revised and substituted by concepts such as the society of knowledge, total quality or pedagogy of competencies and employability ${ }^{1}$.

According to Frigotto (2000) human capital, society of knowledge, total quality or pedagogy of competencies are ideological concepts constructed to sustain the interests of those who control the means of production and do not help reveal the exploitation of workers in contemporary society.

Meanwhile, UNESCO has not offered any break with the concept of education and qualification for labor, although it has sought to expand the concept. The discussion about continued education occupied an outstanding place in the work of the International Commission on Education for the $21^{\text {st }}$ century, coordinated by Jacques Delors. This can be seen in the replacement of the concepts of continuous or permanent education by "education throughout life", based on the four pillars of education: to learn to know, learn to do, learn to live together and learn to be. From this perspective, education throughout life goes beyond the concepts of initial education and permanent education by proposing that it be conceived of more broadly, increasing the equality of opportunities for all people,

[...] offering a second or third chance, satisfying their desire for knowledge and beauty or their desire 
da vida superaria as noções de educação inicial e de educação permanente ao propor que seja concebida de forma mais ampla, aumentando a igualdade de oportunidades a todas as pessoas,

[...] quer se trate de oferecer uma segunda ou uma terceira oportunidade, de dar resposta à sede de conhecimento, de beleza ou de superação de si mesmo, ou ainda ao desejo de aperfeiçoar e ampliar as formações estritamente ligadas às exigências da vida profissional, incluindo formações práticas (DELORS, 1998, p. 117).

Por essas concepções, percebe-se o pressuposto liberal para o qual a desigualdade, ou o não acesso à educação, é uma questão de "falta de oportunidades", não cabendo, portanto, ao indivíduo a responsabilidade pela não qualificação ou pelo desemprego, ignorando-se o processo histórico de assimetria na relação das classes sociais.

Cattani (1996, p. 150) distingue as concepções de educação e de formação, destacando que a primeira pode ser compreendida como um "conjunto de ações, no âmbito das instituições escolares, que visam transmitir conhecimentos gerais e específicos aos alunos, bem como o desenvolvimento de certas atitudes". E que, por sua vez, a formação diz respeito às diferentes ações educativas que se desenvolvem para além ou independentemente do ciclo escolar regular, com o objetivo de desenvolver a capacidade laborativa das pessoas. Assim, segundo o autor, a educação desenvolve-se de forma contínua em determinado espaço de tempo e faixa etária enquanto a formação é mais pontual e aleatória, alcançando diferentes faixas de idade.

De forma mais específica, na literatura pesquisada, há principalmente na área de educação, as denominações: educação permanente, capacitação continuada ou formação continuada. A opção pela denominação última dá-se pela relação com a formação inicial, sendo a continuada uma exigência imperativa e indissolúvel da primeira. Segundo Salles (2004, p. 4),

[...] o processo não pode ser pensado exclusivamente a partir de qualquer uma das suas partes, mas senão de todas elas ao mesmo tempo. Assim como o desenvolvimento profissional não deve ser pensado desvinculado do desenvolvimento da escola e da sociedade, a formação inicial e a formação continuada não devem ser pensadas separadamente.

Isto leva a uma perspectiva de totalidade da velha e da nova questão entre teoria e prática, entre formação e exercício profissional.

Além disso, Salles (2004) afirma que não se pode considerar a prática exclusivamente como critério da verdade sem recorrer a uma atitude maniqueísta sobre a relação dela com a teoria. A isso, acrescenta- to surpass themselves or making it possible to broaden and deepen strictly vocational forms of training, including practical training (DELORS, 1998, p. 117).

These concepts indicate the neoliberal presumption that inequality, or the lack of access to education, is a question of a "lack of opportunities", and the individual is thus not responsible for a lack of preparation or unemployment, ignoring the historic asymmetry in relation of social classes.

Cattani (1996, p. 150) distinguishes between the concepts of education and training, highlighting that the first can be understood as a "set of actions, in the realm of school institutions, that seek to transmit general and specific knowledge to students, as well as the development of certain attitudes". And that, training concerns different educational actions that are undertaken beyond or independently of the regular school cycle, with the goal of developing the labor capacity of individuals. Thus, according to the author, education develops in a continuous manner in a certain space of time and age range, while training is more limited and random, reaching different age ranges.

More specifically, in the literature studied, mainly in the field of education, there are the denominations: permanent education, continuous training or continuous education. The choice for the latter denomination is made because of the relationship with the initial education, with continuation being an imperative requirement that is inseparable from the first. According to Salles (2004, p. 4),

[...] the process cannot be considered exclusively from any one of its parts, but from all at the same time. Thus, since professional development must not be considered separately from the development of the school and society, initial education and continued education should not be thought of separately.

This leads to a perspective of totality of the old and of the new question between theory and practice, between education and professional activity.

In addition, Salles (2004) affirms that practice cannot be considered exclusively as a criterion for truth without falling into a Manichean attitude about the relationship between it with theory. To this is added the relationship between education and the sociooccupational spaces of professional practice. According to Salles, continuing education cannot be understood - and neither can continued education in service - as merely a recycling, or training or improvement.

Reflecting on the work of some authors, Salles emphasizes that there is a tendency to think of continuous education based on a transmission of 
se a relação entre a formação e os espaços sócioocupacionais da prática profissional. Para o autor, não se pode compreender a formação continuada - distinção também à formação continuada em serviço apenas como uma reciclagem, ou um treinamento ou aperfeiçoamento.

Refletindo sobre a produção de alguns autores, Salles enfatiza que há uma tendência de se pensar a formação continuada centrada em transmissão de saberes, enquanto a formação continuada em serviço como aquela com origem e realização na própria prática. Neste aspecto, o conhecimento é tratado de forma dicotômica, denominado de razão técnica e razão prática. A primeira razão parte da teoria para a ação, enquanto a segunda parte da ação para a teoria.

Em Branco (2007, p. 2) encontra-se um ponto de convergência nas concepções de formação continuada e de formação continuada em serviço, a saber:

Podemos conceituar a formação continuada como sendo uma atitude frente aos desafios pedagógicos, políticos e sociais, que deve estar pautada em uma sólida teorização e reflexão. E formação continuada 'em serviço' implica em ser realizada no contexto educativo do tempo e espaço, numa contínua dinâmica de construção do desenvolvimento profissional.

Nessa perspectiva, Salles (2004, p. 4) destaca que o desenvolvimento profissional requer uma sólida formação inicial e continuada "de renovação, extensão e atualização permanente dessa formação". E que, além da universidade, a formação ocorre "também nas lutas democráticas e sindicais, na vida familiar, nos momentos de lazer e fruição estética e em tantos outros [...]", superando as noções de capacitação, treinamento e reciclagem.

Um estudo sobre o estado da arte da formação de professores no Brasil (ANDRÉ et al., 1999, p. 308) aponta a formação continuada como "formação em serviço, enfatizando o papel do professor como profissional e estimulando-o a desenvolver novos meios de realizar seu trabalho pedagógico com base na reflexão sobre a própria prática". Nesse caso, a formação deve se desenvolver ao longo da vida profissional, prioritariamente em unidade escolar.

Dentre as diferentes áreas profissionais com registro de ações voltadas à educação continuada ou permanente, destacam-se as áreas da educação e a da saúde. Na área da saúde, é utilizada a terminologia "educação permanente" para as ações voltadas à qualificação dos profissionais da área, como se verifica na Política Nacional de Formação Permanente em Saúde. Nesse documento, a formação continuada é compreendida como "uma estratégia descontinua de capacitação com rupturas no tempo: são cursos periódicos sem sequência constante" (BRASIL, 2009, p. 44). knowledge, while continuous education in services as something that originates and takes place in the practice itself. In this regard, knowledge is considered in a dualist manner, denominated as technical reason and practical reason. The first leads from theory to action while the second leads from action to theory.

In Branco (2007, p. 2) a point of convergence is found between the concepts of continuous education and continuous education in service, that is:

\begin{abstract}
We can conceive of continuous education as being an attitude taken before pedagogical, political and social challenges, which must be based on a solid theoretical base and reflection. And continuous education 'in service' implies realization in the educational context of time and space, in a continuous dynamic of the construction of professional development.
\end{abstract}

From this perspective, Salles (2004, p. 4) highlights that professional development requires solid initial education and continuous education "of renovation, extension and permanent updating of this education." And that, in addition to the university, education also occurs "in democratic and union struggles, in family life, in moments of leisure and aesthetic fruition, and many others [...]", thus going beyond the notions of preparation, training and recycling.

One study about the state of the art in teacher education in Brazil (ANDRÉ et al., 1999, p. 308) points to continuous education as "education in service, emphasizing the role of the teacher as a professional and stimulating her to develop new ways to conduct her pedagogical work based on a reflection on her own practice." In this case, it is understood that education should take place throughout professional life, particularly in the school.

Among the different professional fields with records of actions aimed at continuous or permanent education, the fields of education and healthcare stand out. In the field of healthcare, the terminology "permanent education" is used for actions aimed at the qualification of professionals in the field, as can be found in the National Policy for Permanent Education in Healthcare. In this document, continuous education is understood as "a discontinuous strategy of education with ruptures in time: they are periodic courses without a constant sequence" (BRASIL, 2009, p. 44).

The same document affirms that permanent education involves the concept of advancement, of change in the practices used to train workers from the field. It thus intends, "to incorporate teachinglearning to the life of the organizations and to the social and labor practices in the context in which they occur" (BRASIL, 2009, p. 45), seeking to overcome the traditional teaching model in the classroom. 
O mesmo documento confere à educação permanente uma concepção de avanço, de mudança nas práticas de capacitação dos trabalhadores da área. Pretende, assim, "incorporar o ensino-aprendizagem à vida das organizações e às práticas sociais e laborais no contexto em que elas ocorrem" (BRASIL, 2009, p. 45), buscando superar o modelo tradicional de ensino em sala de aula.

Nessa concepção de educação permanente, está também contida a ideia de "educação em serviço",

\section{[...] caracterizando-se como um processo educativo a ser aplicado nas relações humanas do trabalho, no intuito de desenvolver capacidades cognitivas, psicomotoras e relacionais dos profissionais, as- sim como seu aperfeiçoamento diante da evolução científica e tecnológica. Dessa maneira, ela eleva a competência e a valorização profissional e institucional (PASCHOAL; MANTOVANI; MÉIER, 2007, p. 480).}

$\mathrm{Na}$ apropriação dos termos de formação continuada, educação permanente, e outros similares no Brasil, é possível identificar que não existe uma definição exata para os conceitos e a respectiva utilização pelos autores.

A partir dessas breves considerações, é pertinente pensar a formação continuada do assistente social na perspectiva do método histórico-dialético, tendo como suporte a categoria da práxis. E, além disso, discutir a necessidade de formação crítica dos assistentes sociais, de modo a qualificar sua prática profissional na direção do compromisso com a classe trabalhadora, na construção de uma sociedade sem desigualdade social.

\section{Formação continuada em Serviço Social}

É no Código de Ética do Assistente Social (CFESS, 1993) que se encontra esta primeira exigência, ao estabelecer: "compromisso com a qualidade dos serviços prestados à população e com o aprimoramento intelectual, na perspectiva da competência profissional". Isto pressupõe a busca constante da qualificação.

Compreende-se que a formação continuada não se reduz ao arsenal técnico-operativo. A razão técnica é tão somente uma estratégia de um processo mais amplo para apreensão da razão ontológica dos processos sociais, circunscritos nas expressões da questão social, objeto da ação profissional do assistente social.

Na literatura pesquisada na área de Serviço Social não se encontrou produção significativa sobre a formação continuada, voltada aos profissionais que se encontram na prática nos diversos espaços sócioocupacionais ${ }^{2}$. De forma singular, há uma produção
This concept of permanent education also contains the idea of "education in service"

\section{[...] characterizing it as an educational process to be applied in human labor relations, in order to develop the cognitive, psychomotor, and relationship abilities of professionals, and to improve them in light of scientific and technological developments. In this way, it emphasizes competence and professional and institutional enhancement (PASCHOAL; MANTOVANI; MÉIER, 2007, p. 480).}

In the appropriation in Brazil of the terms continuous education, permanent education and similar ones, it is possible to identify that there is no precise definition for the concepts and their respective use by the authors.

Based on these brief considerations, it is pertinent to think of continuous education of social workers from the perspective of the historic-dialectic method, supported by the category of praxis. It is also important to discuss the need for critical education of social workers, so that they can qualify their professional practice so that it has a commitment with the working class and the construction of a society without social inequality.

\section{Continuous education in Social Work}

The Code of Ethics for the Social Workers (CFESS, 1993) includes this first requirement, by establishing a: "commitment to the quality of services provided to the population and to intellectual improvement, from the perspective of professional competence." This presupposes the constant search for developing abilities.

It is understood that continuous education is not limited to a worker's technical-operational arsenal. Technical reasoning is merely a strategy for a broader process for understanding the ontological reasoning of social processes, circumscribed in the expressions of the social issue, which is the object of the professional action of the social worker.

In the literature studied in the field of Social Work, there is not a significant amount of study about continuous education aimed at professionals found in the various socio-occupational spaces ${ }^{2}$. Studies do exist in the field of healthcare, specifically about in-service education. Nevertheless, the education of social workers as a continuиm process has been a constant concern of entities in the category including the Federal Social Work Council (Cfess), the Regional Social Work Councils (Cress), the Brazilian Association of Education and Research in Social Work (Abepss) and the National Executive of Social Work Students (Enesso). 
na área da saúde, mais especificamente como formação em serviço. Entretanto, a formação do assistente social como um processo continuum tem sido preocupação constante das entidades da categoria Conselho Federal de Serviço Social (Cfess), Conselhos Regionais de Serviço Social (Cress), da Associação Brasileira de Ensino e Pesquisa em Serviço Social (Abepss) e Executiva Nacional de Estudantes de Serviço Social (Enesso).

O primeiro curso de especialização a distância para os assistentes sociais no Brasil, foi organizado em 1999, pelo conjunto Cfess, Cress, Abepss e Centro de Educação a Distância (CEAD/UnB), com o objetivo de "promover a especialização dos (as) assistentes sociais como forma de qualificar o exercício profissional, a sua inserção atualizada no mundo do trabalho e o fortalecimento do projeto ético-político profissional" (CFESS, 2010).

Em 2009, ocorreu uma segunda edição desse curso, atualizado com os desafios postos ao projeto ético-político e aos enfrentamentos do contexto neoliberal. O curso foi denominado "Direitos sociais e competências profissionais" e desenvolveu-se no período de 2009 a $2010^{3}$.

Ainda com relação às entidades organizativas da profissão, ressaltam-se as iniciativas do conjunto Cfess-Cress que, desde 2000, tem proporcionado seminários sobre a atuação do Serviço Social em áreas específicas, como educação, assistência social, sociojurídica, saúde, previdência, questão urbana, a partir das demandas da categoria ${ }^{4}$. Esse direcionamento pode ser observado nas agendas do Enpess e dos Congressos Brasileiros de Assistentes Sociais $(\mathrm{CBAS})^{5}$, que têm se constituído em espaços de discussão com vistas à melhor qualificação da atuação profissional.

É inegável o crescimento da pós-graduação stricto sensu na área de Serviço Social e o aprofundamento teórico de importantes temáticas que giram em torno da profissão, com boa parte dos profissionais, como mostram as pesquisas ${ }^{6}$, realizando cursos de pós-graduação lato sensu. Porém, mediante a complexidade do exercício profissional, essa questão merece tratamento diferenciado, problematização e busca de alternativas coletivas de enfrentamento.

Sem desconsiderar os determinantes da economia política e a condição de trabalhador assalariado (IAMAMOTO, 1999; 2002), o assistente social tem uma autonomia relativa para a construção de alternativas profissionais. De acordo com Vasconcelos (2007, p. 413), "essas alternativas são possíveis pela rica contraditoriedade do real, mas suas possibilidades de implementação dependem de um sujeito profissional capacitado teórica, técnica e politicamente". Os assistentes sociais expressam um discurso em defesa dos direitos e interesses dos usuários, no entanto, pela avaliação da autora, há uma assimetria
The first distance specialization course for social workers in Brazil was organized in 1999, in a joint effort by Cfess, Cress, Abepss and the Distance Education Center at the University of Brasilia (CEAD/UnB), to "promote the specialization of social workers as a way to qualify professional activity, its revised insertion in the world of work and the strengthening of the professional political-ethical project" (CFESS, 2010).

In 2009, the second edition of this course was realized, revised by the challenges presented to the ethical-political project and by the confrontations in the neoliberal context. The course was denominated "Social Rights and Professional Competencies" and was held from 2009 to $2010^{3}$.

Since 2000, joint initiatives of Cfess-Cress have provided seminars about Social Work in specific fields, such as education, social worker, legal affairs, healthcare, social security and urban issues, based on the needs of the category ${ }^{4}$. This focus can be observed in the agendas of Enpess and the Brazilian Congresses of Social Assistance (CBAS) ${ }^{5}$, which has established discussion spaces aimed at better qualification of professional activity.

There has been undeniable growth in graduate studies in the field of Social Work and a theoretical deepening of important themes related to the profession, with many professionals conducting nondegree oriented graduate courses, as revealed by the studies $^{6}$. Nevertheless, given the complexity of the professional activity, this issue deserves special attention, analysis and a search for collective options to address the issue.

Without disconsidering political-economic determinants and the condition of salaried workers (IAMAMOTO, 1999; 2002), social workers have relative autonomy to construct professional alternatives. According to Vasconcelos (2007, p. 413), "these alternatives are possible because of the rich contradictions presented by reality, but the opportunities for their implementation depend on a professional subject who is theoretically, technically and politically trained". Social workers present a discourse in defense of the rights and interests of users, nevertheless, the author affirms that there is an asymmetry between their intentions and what is realized. Thus, even when social workers opt to articulate their work to the interests of the population "they have not had the objective conditions - based on a critical reading of the specific reality with which they work, as part of and an expression of social reality - to capture the possibilities for action contained in this reality" (VASCONCELOS, 2007, p. 416).

Even recognizing the growth of graduate studies in the field and the broad scholarly bibliography about a wide variety of issues that are involved with the professional activity, in addition to the significant 
entre o intencionado e o realizado. Assim, os assistentes sociais mesmo optando por articular seu trabalho aos interesses da população "não têm tido condições objetivas - a partir de uma leitura crítica da realidade específica com a qual trabalham, como parte e expressão da realidade social - de captar possibilidades de ação contidas nessa realidade" (VASCONCELOS, 2007, p. 416).

Mesmo reconhecendo-se o crescimento da pósgraduação na área e a ampla bibliografia produzida na academia sobre os mais diversos temas que atravessam o exercício profissional, além do significativo avanço político, as respostas profissionais ainda continuam tendo um caráter de descontinuidade e desarticulação. Nessa direção, afirma Paulo Netto (1996, p. 149) que: "a categoria profissional não dispõe de suficientes canais e circuitos que operem uma efetiva socialização" dos avanços acadêmicos.

São situações que demandam um maior investimento dos profissionais na apreciação do seu cotidiano profissional, de forma individual e coletiva, no sentido de criar mecanismos de análise das múltiplas expressões da questão social, assim como estabelecer mediações que possibilitem a elaboração de estratégias para a efetivação do seu projeto ético-político.

\section{Relação teoria-prática: possibilidades de formação continuada}

A formulação de estratégias de formação continuada na relação direta com o exercício profissional tem como pontos de partida a sistematização e a reflexão, a partir do cotidiano profissional. Assinala-se a importância da documentação profissional (relatórios, pareceres, projetos, dentre outros) como elemento vital para construir mediações entre o exercício direto do assistente social e o projeto ético-político profissional, por meio da socialização e do debate coletivo. Retoma-se, a partir de Almeida (2006), a importância do processo de sistematização, que possibilita levantar dados sobre a realidade social e também avaliar as dificuldades, avanços e retrocessos do exercício profissional. Para o autor (ALMEIDA, 2006, p. 403),

\begin{abstract}
O esforço de sistematização como um componente central do trabalho do assistente social não significa, portanto, apenas a geração de dados e informações, mas um processo que envolve a produção, organização e análise dos mesmos, a partir de uma postura crítico-investigativa.
\end{abstract}

Esse processo permite o desvendamento crítico da realidade institucional na qual se insere o assistente social, a construção de mediações com os processos macrossocietários e a problematização "so- political advances, the professional responses are still discontinuous and poorly articulated. In this sense, according to Paulo Netto (1996, p. 149) "the professional category does not have sufficient channels and circuits that activate an effective socialization" of the academic advances.

These circumstances require that professionals make greater efforts to recognize the opportunities that their daily professional activity offers, in an individual and collective manner, to create mechanisms for the analysis of the multiple expressions of the social issue, and to establish mediations that allow developing strategies for the realization of their ethicalpolitical project.

\section{The relation of theory and practice: opportunities for continuous education}

The formulation of strategies for continuous education in direct relation with professional exercise is based on a systematization of and reflection upon the regular activities of Social Work professionals. This is highlighted by the importance of professional documentation (reports, analyses, projects, and other types) as vital elements for the construction of mediations between the direct exercise of social workers and the professional ethical-political project, through socialization and collective debate. Almeida (2006) emphasized the importance of the process of systematization in raising data about social reality and evaluating the difficulties, advances and setbacks of the professional exercise. For the author (ALMEIDA, 2006, p. 403),

\footnotetext{
The effort at systematization as a central component of the work of the social worker does not mean, however, only the generation of data and information, but a process that involves their production, organization and analysis, based on a critical-investigative attitude.
}

This process allows critically revealing the institutional reality in which the social worker is inserted, the construction of mediations with the macro-societal processes and an analysis "of their different dimensions in relation to the daily expressions of social reality, mediated by social policies, social movements, by the form of organization of collective work in institutions, and above all, by social disputes" (ALMEIDA, 2006, p. 403). The systematization provides a revival of "the intellectual dimension given that it places in gear a theoretical reflection, or that is, it revitalizes and revises the theoretical statute for the profession, this is a condition that is socially and institutionally recognized as being necessary for the education of workers in this profession". 
bre suas diferentes dimensões em relação às expressões cotidianas da realidade social, mediatizadas pelas políticas sociais, pelos movimentos sociais, pela forma de organização do trabalho coletivo nas instituições e, sobretudo, pelas disputas societárias" (ALMEIDA, 2006, p. 403). A sistematização propicia a retomada de "sua dimensão intelectual, posto que põe em marcha uma reflexão teórica, ou seja, revitaliza e atualiza o estatuto teórico da profissão, condição social e institucionalmente reconhecida para a formação de quadros nesta profissão".

Já Paulo Netto (1989b, p. 75) assinala a sistematização como um "procedimento prévio e necessário à reflexão teórica", pois na razão dialética conhecese o real por meio de "aproximações sucessivas". Ou seja, a análise do real parte

[...] do empírico (os 'fatos'), apreende as suas relações com outros conjuntos empíricos, pesquisa a sua gênese histórica e o seu desenvolvimento interno e reconstrói, no plano do pensamento, todo este processo.

Então, a cada uma dessas aproximações há um retorno ao

[...] seu ponto de partida; mas os fatos, a cada nova e subsequente abordagem, mostram-se produtos de relações históricas crescentemente complexas e mediatizadas, podendo ser contextualizados de modo concreto e inseridos no movimento macroscópico que os engendra e de que são índices.

Compreende-se a sistematização como um momento prévio ao processo de conhecimento, que possibilita aos assistentes sociais o desvendamento das tendências do real. Battini (1994, p. 144), ao pensar o exercício profissional e a articulação teórico/prática, qualifica a importância da atitude investigativa, isto é, a articulação do acúmulo de conhecimentos já produzidos com a possibilidade de suscitar novas questões a serem pesquisadas. A atitude investigativa permite buscar novas respostas frente aos avanços contidos no projeto ético-político. Segundo Battini, para manter a "prática viva" coloca-se "a exigência [...] da atitude investigativa na direção da permanente busca do novo pela reconstrução de categorias teórico-metodológicas de leitura e intervenção na realidade social."

A atitude investigativa é condição necessária para conhecimento da realidade social para garantir o "reconhecimento da liberdade como valor ético central e das demandas políticas a ela inerentes - autonomia, emancipação e plena expansão dos indivíduos sociais", como afirma o Código de Ética do Assistente Social (CFESS, 1993).

A realidade é rica de novas questões e, para reconhecê-las, exige-se analisar, pensar, questionar,
Meanwhile, Paulo Netto (1989b, p. 75) indicates systematization as a "preliminary procedure that requires theoretical reflection," because in dialectical reasoning reality is discovered by means of "successive approximations". That is, the analysis of the real is based

[...] on the empiric (the 'facts'), apprehending their relations with other empiric groups, studying their historic genesis and their internal development and reconstructing this entire process in the plane of thinking.

Thus, for each one of these approximations there is a return to

[...] their starting point; but the facts, at each new and subsequent approach, display products of increasingly complex and mediated historic relations, which can be contextualized concretely and inserted in the macroscopic movement that engenders them and of which they are indexes.

Systematization is understood as a moment previous to the process of knowing, which allows social workers the tendencies found in reality. Battini (1994, p. 144), upon considering professional exercise and the articulation of theory and practice, qualifies the importance of having an investigative attitude, that is, the articulation of the accumulation of already produced knowledge with the possibility of raising new issues to be studied. An investigative attitude allows seeking new responses to the advances found in the ethical-political project. According to Battini, to maintain a "living practice", "it is necessary to have an investigative attitude towards the permanent search for the new, through the reconstruction of theoretical-methodological categories for reading and intervention in the social reality."

An investigative attitude is a necessary condition for developing the knowledge of social reality that guarantees the "recognition of liberty as a central ethical value and of the political demands that are inherent to it - autonomy, emancipation and the complete expansion of social individuals", as affirmed by the Code of Ethics for the Social Worker (CFESS, 1993).

Reality is rich with new questions and to recognize them it is necessary to analyze, think, question, critically reflect and denaturalize "through the continuous reraising of questions, making them emerge in an increasingly richer and living manner" unveiling the relationship "between the universal and the particular, in a dialectic vision" (BATTINI, 1994, p. 144).

Battini also indicates the need to overcome a pragmatic attitude towards the daily activity of Social Work professionals. The action of social workers, although linked to daily life, must go beyond this. Heller 
refletir criticamente, desnaturalizar "pela contínua recolocação de questões, fazendo-a emergir de forma cada vez mais rica e viva" desvendando a relação "entre o universal e o particular, numa visão dialética" (BATTINI, 1994, p. 144).

Battini indica, além disso, a necessidade de superação do pragmatismo presente no cotidiano profissional. A ação do assistente social, embora se vincule ao cotidiano, precisa ultrapassá-lo. Heller (1985, p. 44) chama esse processo de homogeneização, que concentra "toda a nossa atenção sobre uma única questão" de modo que " suspendemos' qualquer outra atividade durante a execução da anterior tarefa". Cabe aos profissionais criarem estratégias de "suspensão" do cotidiano, por meio da sistematização das informações coletadas sobre os usuários e sua relação com a questão social, para identificar e reconhecer as necessidades sociais e os processos de resistência gestados pelos grupos populares. Esse processo de superação da "superficialidade extensiva" (HELLER, 1985) permite analisar as relações institucionais vinculadas aos projetos de classe e vislumbrar a construção de alianças com outros atores institucionais e com os usuários. Ao mesmo tempo, há a necessidade de criação de espaços para socialização e debate, articulando estratégias de enfrentamento aos limites postos ao exercício profissional, tanto do ponto de vista da inserção na divisão sociotécnica do trabalho, quanto da seletividade e da focalização das tendências das políticas sociais na atualidade.

Pode-se dizer que no exercício profissional as escolhas são "moralmente motivadas" (HELLER, 1985), portanto, frutos de liberdade e autonomia relativas dos sujeitos profissionais, mediante as condições reais nesse contexto. Rompe-se, assim, com a imediaticidade do cotidiano, resultado da atitude investigativa que permite a desmistificação do lugar ocupado pelo assistente social na divisão sociotécnica do trabalho. Esse processo crítico permanente "cria maiores possibilidades de novas explicações, [...] permitindo ir além do limite dado" (BATTINI, 1994, p. 145).

Nessa linha de pensamento, Forti e Guerra (2010) afirmam que, mediante a complexidade da formação e do exercício profissional, torna-se imprescindível ao assistente social o conhecimento da totalidade social para uma atuação séria e competente. Para as autoras, é "necessária uma visão dos pro-
(1985, p. 44) calls this a process of homogenization, which concentrates "all of our attention on a single question" so that we "suspend" any other activity during the execution of the anterior task." It is up to professionals to create strategies for the "suspension" of daily work, by systematizing information collected about users and their relation with social issues, to identify and recognize social needs and the processes of resistance developed by popular groups. This process of overcoming the "extensive superficiality" (HELLER, 1985) allows analyzing the institutional relationships linked to projects of class and envisioning the construction of alliances with other institutional actors and users. At the same time, there is a need to create spaces for socialization and debate, articulating strategies to confront the limits placed on professional exercise, both from the perspective of the insertion in the socio-technical division of labor, and in the selectivity and focalization of the trends of current social policies.

It can be said that during professional activity, choices are "morally motivated" (HELLER, 1985), and therefore the fruits of liberty and the relative autonomy of the professional subjects, in light of the real conditions in this context. There is thus a break with the immediate nature of daily life, which is the result of the investigative attitude that allows the demystification of the place occupied by the social worker in the sociotechnical division of labor. This permanent critical process "creates greater possibilities for new explanations [...] allowing going beyond the established limit" (BATTINI, 1994, p. 145).

In this line of thinking, Forti and Guerra (2010) affirm that given the complexity of education and professional activity, it becomes essential for social worker to have knowledge of social reality to be able to act competently and responsibly. For these authors, it is "necessary to have a vision of social processes as totalities that are composed of various factors and realms and which present different levels of complexity". They affirm that it is necessary to have "a theory that allows us to perceive how the central contemporary dilemmas are translated in the peculiarities of Social Work and expressed in the socio-professional requests and competencies and in the professional culture" (FORTI; GUERRA, 2010, p. 3). 
cessos sociais como totalidades que se compõem de vários aspectos e âmbitos e que apresentam diferentes níveis de complexidade". E prosseguem afirmando que é preciso "uma teoria que nos permita perceber como os principais dilemas contemporâneos se traduzem nas peculiaridades do Serviço Social e se expressam nas requisições e competências socioprofissionais e na cultura profissional" (FORTI; GUERRA, 2010, p. 3).

No entanto, as autoras alertam sobre a necessidade de romper com a visão instrumental da teoria que a concebe como modelo, remetendo a uma visão funcional e pragmática da mesma. E reforçam: "é como se a validade da teoria repousasse na dócil submissão à necessidade de respostas práticas imediatas para os problemas". A visão pragmática da teoria não permite compreender a complexidade do real, dentro de uma perspectiva dialética, pois "ao suprimir as mediações sociais constitutivas e constituintes dos processos, o pensamento reificado não ultrapassa a aparência dos fatos" (FORTI; GUERRA, 2010, p. 5, 7).

Com base nessa argumentação, esta pesquisa desenvolve a ideia de que o assistente social - inserido na divisão sociotécnica do trabalho, com o suporte teórico enunciado desde o final dos anos 1970 - é capaz de formular respostas mais abrangentes no cotidiano profissional, a partir do reconhecimento das expressões da questão social, das tendências das políticas sociais e do conhecimento dos usuários. Por entender-se que a prática "[...] não é uma atividade qualquer, mas uma atividade que possibilita ao sujeito reflexão sobre sua ação e revelações sobre a realidade - que possibilita decifração das categorias e captação da legalidade do fenômeno" (FORTI; GUERRA, 2010, p. 4). Para tanto, torna-se indispensável resgatar o papel da consciência, da teleologia, da relação com os projetos profissionais e societários, objetivando a superação de uma visão academicista, abstrata e pragmática da teoria e da prática.

Em face da complexidade das demandas sociais, é preciso encontrar respostas, num processo de reflexão que ultrapasse o atendimento imediato e necessário, pois, a prática "é uma ação capaz de proporcionar conhecimentos, transformando e qualificando nossas ideias sobre as coisas e de nos fornecer meios, caso tenhamos intenção de modificá-las" (FORTI; GUERRA, 2010, p. 4).

Assim, busca-se problematizar a formação continuada como um processo constante e necessário ao exercício profissional, imbricado na relação teórico-prática. Processo que parte da qualificação da produção documental e da apropriação das novas tecnologias. Considera-se que a atitude investigativa propricia ao sujeito profissional colocar-se em uma perspectiva crítica, que além de trazer à tona a realidade social vivenciada no cotidiano institucional também possibilita formular es-
Nevertheless, the authors warn about the need to break with an instrumental vision of theory that conceives it as a model, and refer to a functional and pragmatic vision of theory. They emphasize: "it is as if the validity of a theory is based on docile submission to a need for immediate practical responses to problems". A pragmatic view of theory does not allow understanding the complexity of the real from a dialectical perspective, because "by suppressing the social mediations that are constitutive of and constituent to the processes, reified thinking does not go beyond an appearance of the facts" (FORTI; GUERRA, 2010, p. 5, 7).

Based on this argument, this essay affirms that social workers - inserted in the socio-technical division of labor, with the theoretical support advanced since the late 1970s - are capable of formulating broader responses to the daily activity of professionals, based on recognition of the expressions of the social question, trends in social policies and the knowledge of users. To do so, it must be understood that the practice "[...] is not just any activity, but an activity that allows deciphering categories and capturing the legality of the phenomenon" (FORTI; GUERRA, 2010 , p. 4). Therefore, it becomes indispensable to revive the role of the conscious, of teleology, of the relationship with professional and social projects, seeking to overcome an academic, abstract and pragmatic view of theory and practice.

Considering the complexity of social demands, it is necessary to find responses, through a process of reflection that goes beyond the immediate and necessary service, because practice "is an action capable of providing knowledge, transforming and qualifying our ideas about things and of providing us means, if we have an intention of changing them" (FORTI; GUERRA, 2010, p. 4).

Thus, continuous education is considered as a constant and necessary process for professional activity, which is imbricated in the relation of theory and practice. It is a process that is based on the qualification of the production of documents and on the appropriation of new technologies. It is considered that the adoption of an investigative attitude allows the professional subject to take a critical perspective, which beyond bringing to light the social reality experienced in the daily institutional activity, also allows formulating collective strategies to confront the targeting and selectivity of social policies.

\section{Final considerations}

This study reaffirmed the need for articulation between theory and practice and recognizes the existence of a considerable theoretical and political background in the profession. It noted, however, certain 
tratégias coletivas de enfrentamento à focalização e à seletividade das políticas sociais.

\section{Considerações finais}

Neste estudo, reafirma-se a necessidade da articulação entre a teoria e a prática e se reconhece a existência de um grande acúmulo teórico e político na profissão. Observa-se, porém, certa dificuldade na utilização desses saberes como referencial teórico que sustente o exercício profissional.

Nas pesquisas realizadas sobre o mercado de trabalho do assistente social, citadas ao longo do texto, é recorrente a afirmação de que há pouco reconhecimento e pouca autonomia profissional. Esse estado de coisas pode ser explicado pela inserção dos assistentes sociais na divisão sociotécnica do trabalho aliado às dificuldades em responder às reais demandas da população. Contudo, se essas dificuldades relacionam-se diretamente a questões estruturais, é possível inferir que há fragilidades esparsas, também nos campos político e teórico.

Há ainda muitas questões a serem investigadas, mas ficou evidente que o processo de formação profissional continuada é uma importante estratégia para a superação dos limites teórico-políticos mencionados em relação ao exercício e ao projeto ético-político profissionais.

É fundamental a retomada desse tema de forma crítica, na perspectiva dialética, visando a superação de uma prática rotineira, empiricista, fragmentada, desarticulada e de uma teoria apreendida apenas de forma academicista. É fundamental, também, a retomada da noção de indissociabilidade entre a teoria e a prática. Paulo Netto (1996) já identificava na década de 1990 a existência do distanciamento entre as agências de formação e o campo do exercício profissional. Sabe-se que é papel da universidade a produção de conhecimentos, mas também o acompanhamento dos profissionais para além dos cursos de pós-graduação lato e stricto sensu.

Cabe por fim lembrar o compromisso social da Universidade afirmado pela Política Nacional de Extensão Universitária ao destacar a indissociabilidade entre ensino, pesquisa e extensão, como "processo interdisciplinar, educativo, cultural, científico e político que promove a interação transformadora entre Universidade e outros setores da sociedade"?.

É possível pensar e propor ações concretas que efetivem o papel da universidade no fomento a discussões temáticas realizadas em conjunto pelos professores, profissionais e estudantes da graduação e pós-graduação, seja por meio dos fóruns de supervisão, seminários, análises de conjuntura ou por outras estratégias de formação continuada, de modo articulado a movimentos sociais, sindicatos e outros segmentos organizados. difficulties in the use of this knowledge as a theoretical reference that sustains professional activity.

In the studies conducted about the labor market for social workers, mentioned during the article, there are recurring affirmations that professionals are poorly recognized and have little autonomy. This state of things can be explained by the insertion of social workers in the socio-technical division of labor allied to difficulties in responding to the population's real needs. Nevertheless, if these difficulties are directly related to structural issues, it is possible to infer that there are also scattered weaknesses in the political and theoretical fields.

There are still many issues to be studied, but it is clear that continuous professional education is an important strategy for overcoming the theoreticalpolitical limits mentioned in relation to the activity and the ethical-political project of professionals.

It is essential to address this issue critically, from a dialectical perspective, seeking to overcome routine empiricist, fragmented, disarticulated practices, and theory that is only grasped in an academic manner. It is also essential to reconsider the concept of the inseparability between theory and practice. In the 1990s, Paulo Netto (1996) identified the distance between educational agencies and the field of professional activity. The role of the university is to produce knowledge, but also to accompany professionals beyond their graduate courses (whether in degree programs or not).

Finally, it is important to remember the social commitment of the university as affirmed by the National University Extension Policy which emphasizes the inseparability of teaching, research and extension, as "an interdisciplinary, educational, cultural, scientific and political process that promotes the transformative interaction between the university and other sectors of society"7.

It is possible to think of and propose concrete actions that effectuate the role of the university in supporting thematic discussions, realized in conjunction by professors, professionals and undergraduate and graduate students, whether by means of forums on supervision, seminars, analyses of the political, economic and social situation or by other strategies for continuous education, in a way that is articulated to social movements, unions and other organized segments.

\section{Notes}

1 For more about the issue, see Frigotto (2005).

2 A survey was conducted of the most recent theoretical production about Social Work in the following periodicals: Revista Katálysis, Serviço Social \& Sociedade, Temporalis; and consultation was 


\section{Referências [References]}

ALMEIDA, N. L. T. de. Retomando a temática da sistematização da prática. In: BRAVO, M. I.; MOTA, A. E.; TEIXEIRA, M. Serviço Social e saúde: formação e trabalho profissional. São Paulo: Cortez, 2006, p. 399-408.

ANDRE, M. et al. Estado da arte da formação de professores no Brasil. Educação e Sociedade, ano 20, n. 68, p. 301-309, dez. 1999.

BATTINI, O. Atitude investigativa e formação profissional. Serviço Social \& Sociedade, São Paulo: Cortez, ano XV, n. 45, p. 142-147, abr. 1994.

BRANCO, C. Formação continuada de professores: focalizando a relação teoria-prática. 2007. Disponível em: <http:// www.gestaoescolar.diaadia.pr.gov.br/arquivos/File/producoes pde/ artigo cristina branco.pdf>. Acesso em: 1 mar. 2012.

BRASIL. Política Nacional de Educação Permanente em Saúde. Brasília: Ministério da Saúde, 2009.

BRITO, L. C. de. A ideologia da qualificação, trabalho e a ampliação do mercado da educação superior. COLÓQUIO INTERNACIONAL MARX ENGELS, 5. Anais... Unicamp, 2007. Disponível em: <http://www.unicamp.br/cemarx/ anais v coloquio arquivos/arquivos/comunicacoes/gt5/sessao2/ Leonardo\%20 Brito.pdf>. Acesso em: 25 fev. 2012.

CATTANI, A. D. Trabalho e autonomia. Petrópolis: Vozes, 1996.

CFESS. Código de Ética do Assistente Social. 1993. Disponível em: 〈http://www.cfess.org.br/arquivos/CEP 1993.pdf >. Acesso em: 10 mar. 2012.

. Curso de Especialização lato sensu do Cfess e Abepss chega ao fim neste mês, 28 out. 2011. Disponível em: <http:// www.cfess.org.br/noticias res.php?id=500>. Acesso em: $10 \mathrm{mar}$. 2012.

Relatório final. In: ENCONTRO NACIONAL CFESS/ CRESS, 40, 2011. Disponível em: 〈http://www.cfess.org.br/ arquivos/relatoriofinal 40NACIONAL.pdf $>$. Acesso em: $25 \mathrm{fev}$. 2012.

DELORS, J. (Coord.). Educação: um tesouro a descobrir. Relatório para a UNESCO da Comissão Internacional sobre Educação para o século XXI. São Paulo: Cortez, Brasília: UNESCO, 1998.

FARIA, S. Produção do conhecimento e agenda socioprofissional do Serviço Social brasileiro. 2003. Tese (Doutorado em Serviço Social) - PUC-SP, São Paulo, 2003.

FORTI, V.; GUERRA, Y. Na prática a teoria é outra? In: (Org.). Serviço Social: temas, textos e contextos. Rio de

Janeiro: Lumen Juris, 2010, p. 3-22. made of the websites of the Federal Social Work Council (Cfess) and of the Brazilian Association of Teaching and Research in Social Work (Abepss), of the annals of the XI and XII National Encounters of Researchers in Social Work (Enpess) and of the XII and XIII Brazilian Congresses of Social Workers (CBAS).

3 It should be highlighted that the 40th National Encounter Cfess/ Cress, held in Brasília, from Sept. 8 - 11, 2011, approved the National Permanent Education Policy for Social Workers, planned for implementation in 2012, as indicated in the Final Report [Relatório Final] (CFESS, 2011).

4 In the 2010-2012 administration of Abepss, the "Itinerant Abepss" project was developed in conjunction with Cfess, planned for implementation in 2012. Its goals include: strengthening the politicalpedagogical strategies for facing the weakening of higher education, by broadly promoting its principles, content and the challenges raised for the consolidation of the circular guidelines (CFESS, 2011, p. 7). This project is aimed, above all, at the continued education of professionals - teachers and field supervisors and to graduate students - who have direct relations with initial education.

5 About this, see Faria (2003).

6 These include the national study, with the reference Trindade, Amaral and Tenório (2007, p. 6), coordinated by the Federal Social Work Council: " $55.34 \%$ have only a graduate degree; followed by those who have some specialized training (36.26\%) and those who have master's, doctorate's and post doctorate's, in a much lower percentage, indicating that non-degree graduate courses are still those most accessible, although for only just a bit more than $1 / 3$ or the category". There is also a study coordinated by Jamur, Frizzera and Manfroi (2003), at Abepss in the Eastern Region that shows that of the 22 social workers studied, 21 had taken some graduate level course. Meanwhile, a study conducted in Espírito Santo (MANFROI et al., 2007), found that of the total of 200 social workers interviewed, 60 had only undergraduate studies, 117 had taken specialization courses, 13 had completed a master's, 2 had Ph.Ds. In Santa Catarina (MANFROI et al., 2011), 38 social workers had only graduate education, 64 some specialization courses, 18 were master's, 10 had doctorate's and 2 had post-doctoral study.

7 From the document Política Nacional de Extensão Universitária. Available at: <http://www.renex.org.br/documentos/ColecaoExtensao-Universitaria/01-Plano-Nacional-Extensao/Planonacional-de-extensao-universitaria-editado.pdf $>$. Accessed on: Feb. $15,2012$. 
FRIGOTTO, G Os delírios da razão: crise do capital e metamorfose conceitual no campo educacional. In: GENTILLI, P. (Org.). Pedagogia da exclusão:crítica ao neoliberalismo em educação. Tradução de Vania Paganini Thurler e Tomaz Tadeu da Silva. Petrópolis: Vozes, 2000, p. 77-108. (Coleção Estudos Culturais em Educação).

Capital humano. Dicionário da educação pro-fissional em saúde, 2009. Disponível em: <http://www.epsjv.fiocruz.br/ dicionario/verbetes/caphum.html>. Acesso em: 12 fev. 2012.

HELLER, A. $O$ cotidiano e a história. Rio de Janeiro: Paz e Terra, 1985.

IAMAMOTO, M. V. O Serviço Social na contemporaneidade: trabalho e formação profissional. São Paulo: Cortez, 1999.

. Projeto profissional, espaços ocupacionais e trabalho do assistente social na atualidade. In: CFESS (Org.). Atribuições privativas do(a) assistente social em questão. Brasília: Cfess, 2002.

JAMUR, M.; FRIZZERA, Y.; MANFROI, V. M. Relatório de Pesquisa. Em busca das mudanças: a prática do serviço social na Região Abepss-Leste (1980/2003). Rio de Janeiro, 2003. Trabalho acadêmico.

MANFROI, V. M. et al. Relatório de pesquisa: o mercado de trabalho dos assistentes sociais no Espírito Santo. Vitória, 2007. (digitalizado).

MANFROI, V. M. et al. A realidade profissional dos assistentes sociais de Santa Catarina: mercado de trabalho, exercício e formação profissional. Florianópolis, 2011. (digitalizado).

PASCHOAL, A. S.; MANTOVANI, M. F.; MÉYER, V. M. J. Percepção da educação permanente, continuada e em serviço para enfermeiros de um hospital de ensino. Rev. esc. enferm.USP, v. 41, n. 3, p. 478-84, 2007.

PAULO NETTO, J. Notas para a discussão da sistematização da prática e teoria em Serviço Social. Caderno ABESS, São Paulo: Cortez, n. 3, p. 141-153, 1989a,

. Para a crítica da vida cotidiana. In: PAULO NETTO, J.; CARVALHO, M. do C. B. de. Cotidiano: conhecimento e crítica. São Paulo: Cortez, 1989b, p. 64-93.

Transformações societárias e Serviço Social: notas para uma análise prospectiva da profissão no Brasil. Serviço Social \& Sociedade, São Paulo: Cortez, n. 59, p. 86-132, abr. 1996.

SALLES, F. C. A formação continuada em serviço. Revista Iberoamericana de Educación, 2004. Disponível em: 〈http:// www.rieoei.org/deloslectores/806Casadei.PDF>. Acesso em: 1 mar. 2012.

SCHULTZ, T. W. O capital humano. Investimentos em educação e pesquisa. Tradução de Marco Aurélio de Moura Matos. Rio de Janeiro: Zahar Editores, 1973 [1971].

\section{Ana Maria Baima Cartaxo}

ana.cartaxo@ufsc.br

$\mathrm{PhD}$ in Social Work from the Pontifical Catholic

University of São Paulo (PUC-SP)

Adjunct Professor in the Department of Social

Work at the Federal University at Santa Catarina (UFSC)

\section{Vania Maria Manfroi}

vaniamanfroi@yahoo.com.br

$\mathrm{PhD}$ in Social Work from PUC-SP

Associate Professor II from the Dept. of Social Work at UFSC

Maria Teresa dos Santos

teresasantos@cse.ufsc.br

$\mathrm{PhD}$ in Social Work from PUC-SP

Adjunct Professor II in the Dept. of Social Work at UFSC

\section{Department of Social Work - UFSC}

Campus Universitário Reitor João David Ferreira

Lima

Trindade

Florianópolis - Santa Catarina

CEP: 88040-970 
TRINDADE, R. L. P.; AMARAL, M. V. B.; TENÓRIO, M. D. O perfil profissional do assistente social no Brasil. In: CONGRESSO BRASILEIRO DE SOCIOLOGIA, 13. Anais... Recife. 2007.

VASCONCELOS, A. M. de. Para além da escolha de Sofia: tendências atuais da prática profissional dos assistentes sociais na rede de saúde do município do Rio de Janeiro. In:

(Ed.). A prática do Serviço Social: cotidiano, formação e alternativas na área da saúde. São Paulo: Cortez, 2007, p. 413507.

\section{Notas}

1 Para aprofundamento do tema, ver Frigotto (2005).

2 Foi realizado um levantamento da produção teórica mais recente do Serviço Social nos seguintes periódicos: Revista Katálysis, Serviço Social \& Sociedade, Temporalis; foram verificados os sítios eletrônicos do Conselho Federal de Serviço Social (Cfess) e da Associação Brasileira de Ensino e Pesquisa em Serviço Social (Abepss), os anais dos XI e XII Encontros Nacionais de Pesquisadores em Serviço Social (Enpess) e dos XII e XIII Congressos Brasileiros de Assistentes Sociais (CBAS).

3 Cabe destacar que o 40. Encontro Nacional Cfess/Cress, realizado em Brasília, no período de 8 a 11 de setembro de 2011, em uma de suas deliberações, aprovou a Política Nacional de Educação Permanente para assistentes sociais, com previsão de implementação a partir de 2012, conforme consta em seu Relatório Final (CFESS, 2011).

4 A Abepss na gestão 2010-2012 em convênio como Cfess elaborou o projeto “Abepss Itinerante", com previsão de implantação ainda em 2012, cujo objetivo é: fortalecer as estratégias políticopedagógicas de enfrentamento à precarização do ensino superior, por meio da difusão ampla dos princípios, conteúdos e desafios colocados para a consolidação das diretrizes curriculares (CFESS, 2011,p. 7).Este projeto destina-se, sobretudo, à formação continuada dos profissionais - professores e supervisores de campo e aos estudantes de pós-graduação - diretamente relacionados com a formação inicial.

5 A este respeito, ver Faria (2003).

6 Entre essas, a pesquisa nacional, referenciado por Trindade, Amaral eTenório (2007,p. 6), coordenada pelo Conselho Federal de Serviço Social: " $55,34 \%$ possuem apenas a graduação; seguem-se os (as) que são especialistas $(36,26 \%)$ e os (as) que são mestres, doutores (as) e pós-doutores (as), com índices bem inferiores, mostrando que a pós-graduação lato sensu ainda é a mais acessível, embora para um pouco mais de 1/3 da categoria”. Há, também, a pesquisa coordenada por Jamur, Frizzera e Manfroi (2003), na Abepss da Região Leste que mostra que dos 22 assistentes sociais pesquisados, 21 tinham curso de pós-graduação. Já, em pesquisa realizada no Espírito Santo (MANFROI et al., 2007), observou-se que do total de 200 entrevistados, 60 tinham apenas graduação, 117 eram especialistas, 13 mestres, 2 doutores e 2 pós-doutores. Em Santa Catarina (MANFROI et al., 2011), 38 assistentes sociais eram apenas graduados, 64 especialistas, 18 mestres, 10 doutores e 2 pós-doutores.

7 Extraído do documento Política Nacional de Extensão Universitária. Disponível em: 〈http://www.renex.org.br/documentos/ColecaoExtensao-Universitaria/01-Plano-Nacional-Extensao/Planonacional-de-extensao-universitaria-editado.pdf> . Acesso em: 15 fev. 2012.

\section{Ana Maria Baima Cartaxo \\ ana.cartaxo@ufsc.br}

Doutora em Serviço Social pela Pontifícia Universidade Católica de São Paulo (PUC-SP)

Professroa Adjunta no Dep. de Serviço Social da Universidade Federal de Santa Catarina (UFSC)

\section{Vania Maria Manfroi}

vaniamanfroi@yahoo.com.br

Doutora em Serviço Social pela PUC-SP

Professora Associada II no Dep. de Serviço Social da UFSC

\section{Maria Teresa dos Santos}

teresasantos@cse.ufsc.br

Doutora em Serviço Social pela PUC-SP

Professora Adjunta II no Dep. de Serviço Social da UFSC

\section{Departamento de Serviço Social - UFSC}

Campus Universitário Reitor João David Ferreira Lima, Trindade

Florianópolis - Santa Catarina

CEP: 88040-970 